NBER WORKING PAPER SERIES

\title{
DOES HUMAN CAPITAL TRANSFER FROM PARENT TO CHILD? THE INTERGENERATIONAL EFFECTS OF COMPULSORY SCHOOLING
}

\author{
Philip Oreopoulos \\ Marianne E. Page \\ Ann Huff Stevens \\ Working Paper 10164 \\ http://www.nber.org/papers/w10164
}

\author{
NATIONAL BUREAU OF ECONOMIC RESEARCH \\ 1050 Massachusetts Avenue \\ Cambridge, MA 02138 \\ December 2003
}

\begin{abstract}
We would like to thank Adriana Lleras-Muney, Joshua Angrist, and Daron Acemoglu for making available the data from their work on compulsory schooling laws. Melanie Guldi and Sami Kitmitto provided invaluable research assistance. We are grateful to seminar participants at UC-Davis, the University of Toronto, and Duke University for their helpful comments. The views expressed herein are those of the authors and not necessarily those of the National Bureau of Economic Research.
\end{abstract}

C2003 by Philip Oreopoulos, Marianne E. Page, and Ann Huff Stevens. All rights reserved. Short sections of text, not to exceed two paragraphs, may be quoted without explicit permission provided that full credit, including $\odot$ notice, is given to the source. 
Does Human Capital Transfer from Parent to Child? The Intergenerational

Effects of Compulsory Schooling

Philip Oreopoulos, Marianne E. Page, and Ann Huff Stevens

NBER Working Paper No. 10164

December 2003

JEL No. I2, J6

\begin{abstract}
The strong correlation between parents' economic status and that of their children has been welldocumented, but little is known about the extent to which this is a causal phenomenon. This paper attempts to improve our understanding of the causal processes that contribute to intergenerational immobility by exploiting historical changes in compulsory schooling laws that affected the educational attainment of parents without affecting their innate abilities or endowments. We examine the influence of parental compulsory schooling on grade retention status for children aged 7 to 15 using the 1960, 1970 and 1980 U.S. Censuses. Our estimates indicate that a one-year increase in the education of either parent reduces the probability that a child repeats a grade by between two and seven percentage points. Among 15 to 16 year olds living at home, we also estimate that parental compulsory schooling significantly lowers the likelihood of dropping out. These findings suggest that education policies may be able to reduce part of the intergenerational transmission of inequality.
\end{abstract}

$\begin{array}{lll}\text { Philip Oreopoulos } & \text { Marianne E. Page } & \text { Ann Huff Stevens } \\ \text { Department of Economics } & \text { Department of Economics } & \text { Department of Economics } \\ \text { University of Toronto } & \text { University of California, Davis } & \text { One Shields Avenue } \\ \text { 150 St. George Street } & \text { Davis, CA 95616-8578 } & \text { University of California, Davis } \\ \text { Toronto, ON M5S 3G7 } & \text { and NBER } & \begin{array}{l}\text { Davis, CA 95616 } \\ \text { and NBER }\end{array} \\ \text { Canada } & \text { mepage@ucdavis.edu } & \begin{array}{l}\text { annstevens@ucdavis.edu } \\ \text { and NBER }\end{array} \\ \text { oreo@economics.utoronto.ca } & & \end{array}$




\section{Introduction}

A high degree of persistence in economic status exists across generations, but we know very little about the causal processes that drive this phenomenon. For example, children who grow up in more highly educated families have better labor market outcomes as adults than children who grow up in less educated families, but we do not know whether this is because education bestows parents with skills that make them better parents or because genetic or environmental factors that contributed to the parents' educational levels are shared by their children. This paper attempts to improve our understanding of the causal processes that contribute to intergenerational immobility by exploiting historical changes in compulsory schooling laws that affected the educational attainment of parents without affecting their innate abilities. Quantifying the extent to which children's well-being can be improved by increasing their parents' education also has important implications for public policy: most discussions about the government's role in providing educational aid, for example, focus on the individual's return to education and ignore the possibility of social benefits. Knowing that there are intergenerational returns to increased schooling would provide a further rationale for such programs.

Few studies have attempted to isolate the causal effect of education on the next generation's well-being. This is at least partly due to the fact that it is difficult to find plausible sources of identifying variation. It is also hard to find large, nationally representative datasets that simultaneously provide information on parental characteristics and children's outcomes. Our use of compulsory schooling laws applied to Census data allow us to overcome both of these problems. Several studies have already demonstrated a strong relationship between these laws 
and individuals' educational attainment. Angrist and Krueger (1991) provided the initial intuition behind this natural experiment when they used quarter of birth to identify the wage return to education on the grounds that those who were born in later quarters of the year were compelled to get more education because compulsory education laws forced students to stay in school until they reached a certain age. ${ }^{1}$ More recent studies examine how changes in the school leaving laws and child labor laws themselves correlate with school attainment across region and over time. Lleras-Muney (2001) and Goldin and Katz (2003) show that these laws were effective at raising education levels in the United States. Harmon and Walker (2000) and Oreopoulos (2003) find similar effects on education attainment from changes in compulsory schooling in the United Kingdom and Canada. Lleras-Muney also investigates the origins of these laws in the United States and concludes that the law changes were not driven by underlying trends in educational attainment but by exogenous political factors. Previous studies have used these laws to examine the effects of education on earnings [Acemoglu and Angrist, 1999], criminal activity [Lochner and Moretti, 2001], mortality [Lleras-Muney, 2002], and subjective measures of well-being [Oreopoulos, 2003], but this is the first study to estimate the intergenerational effects of the U.S. laws.

Our main analysis is based on a sample of children ages 7-15 taken from the 1960, 1970 and 1980 individual U.S. Census files. We examine the effects of parental education on children's grade retention, and find a substantial and significant positive effect of parental education on children's human capital accumulation. This effect is somewhat larger than OLS estimates would suggest. The estimates indicate that a one-year increase in the education of

\footnotetext{
${ }^{1}$ Subsequent studies question whether the quarter-of-birth variable is a valid instrument in these analyses. Bound, Jaeger, and Baker (1995) and Bound and Jaeger (1997) for example, show that education attainment and quarter of birth are only weakly correlated, and that weakly correlated instruments can generate estimates that are biased in the same direction as OLS. Compulsory schooling laws are much more strongly correlated with educational attainment than individuals' quarters of birth, however.
} 
either parent reduces the probability that a child repeats a grade by between two to seven percentage points, and indicate that parental education has an independent and significant effect on children's education outcomes.

The remainder of the paper is organized as follows: Section II describes related studies that attempt to understand the relationship between parents' education and children's outcomes. Sections III and IV outline our empirical strategy and data, respectively. We present our results in Section V and draw conclusions from them in Section VI.

\section{Background Literature}

A few previous studies have attempted to isolate the causal influence of parental education by comparing siblings. Behrman and Rosenzweig (2002) for example, use within twin variation in education to identify the effects of twin mother's schooling on the educational attainment of their offspring. An advantage of this approach is that it controls for all unobserved mother characteristics that are common to twins. A disadvantage of this approach, however, is that it may exacerbate biases if within twin pair differences in characteristics give rise to the differences in their education levels and also affect their children's outcomes. ${ }^{2}$ Within twin estimates are also known to be more prone to measurement error problems (Griliches, 1979). Rosenzweig and Wolpin (1994) compare test scores of siblings whose mothers increased their schooling in between births and find evidence that additional maternal education improves students' test scores. Using a similar strategy, Currie and Moretti (2002) find that higher maternal education improves infant health. This estimation strategy provides the opportunity to control for mother fixed effects, yet, it is not clear whether the observed improvements in

${ }^{2}$ Behrman, Rosenzweig, and Taubman (1994), for example, find birth weight differences between twins correlate significantly with schooling differences and subsequent earnings. Recent work by Antonovics and Goldberg (2003) questions the robustness of the Behrman and Rosenzweig's (2002) results. 
children's test scores are driven by changes in mother's schooling or whether they are driven by other changes in the mother's circumstances over time that might be correlated with schooling. Sacerdote (2000) compares socioeconomic outcomes of adoptees that were randomly assigned to their adoptive parents and finds no evidence that the adoptive parents' education affects their children's outcomes. ${ }^{3}$ This approach is appealing because it is impossible to ascribe the intergenerational link to a genetic inheritance, but it does not entirely eliminate the possibility of selection bias since even with random assignment parents have the ability to turn a child down. In addition, an observed correlation could be driven by parental characteristics that are not genetically transmitted to children but that nevertheless affect both individual and offspring's human capital accumulation. ${ }^{4}$

Most existing studies have also relied on small, nonrepresentative, datasets. The Behrman and Rosenzweig study, for example, uses samples of 212 female twin pairs and 122 male twin pairs who participated in the Minnesota Twin Registry. Rosenzweig and Wolpin (1994) use a sample of unusually young mothers from the NLSY. Likewise, Sacerdote's analyses focus on fewer than 200 adoptees per sample who were born in Britain (the first sample) or adopted in Colorado (the second sample).

Our approach is similar in spirit to another estimation strategy undertaken by Currie and Moretti (2002), which isolates the effect of mothers' education on birth outcomes (birthweight and gestational age) using county level data on college openings between 1940 and 1990 to capture differences in the availability of educational services among different cohorts of women giving birth in the same county and year. These differences are then used to identify differences

\footnotetext{
${ }^{3}$ He does find evidence that parents' education matters among adopted children in the NLSY, but these children were not necessarily randomly assigned to their adoptive parents.

${ }^{4}$ For example, if characteristics that lead to higher education levels also contribute to better parenting skills independent of the level of education, then researchers' inability to control for these characteristics will result in upward biased estimates of education effects.
} 
in mothers' education levels. The authors estimate that an additional year of maternal education reduces the incidence of low birth weight by approximately ten percent, and the incidence of preterm birth by approximately six percent.

Like Currie and Moretti, we also use geographic/cohort/year variation to identify the effect of parental education. Another similarity between our study and theirs is that both employ large datasets, although Currie and Moretti's data are only from California. One concern with Currie and Moretti's identification strategy is that differences in the density of post secondary institutions may reflect differences in demand for college, which may in turn be correlated with parental characteristics that determine children's outcomes. For example, college openings may happen as a response to increases in the number of qualified students who live in the area, and changes in the degree of college preparedness may affect future generations' well-being whether or not the parent actually goes to college.

It is worthwhile to highlight some key differences between our study and theirs. First, we use a different source of identifying variation. We will argue that changes in compulsory schooling laws are unlikely to be correlated with individual characteristics other than schooling. In addition, the law changes that we use to identify the effects of parental education will affect a different part of the education distribution relative to the instruments used by Currie and Moretti: changes in compulsory schooling laws will affect parents with low levels of education, whereas changes in the number of post secondary institutions will affect those with higher levels of education. One might expect that an additional year of schooling would have more impact among those with relatively little education. Another difference is that we focus on children's human capital accumulation instead of health outcomes. Finally, our study allows us to examine 
the effects of both mothers' and fathers' education levels, whereas Currie and Moretti's data only contain information on mothers' education level.

Recent papers by Chevalier (2003) and Black, Devereux and Salvanes (2003) also use changes in compulsory schooling laws to identify the effect of parental education on the next generation's outcomes. Chevalier's study uses a change in the compulsory schooling requirement that took place in Britain in 1957. He finds large effects of mother's education on children's educational attainment, but does not find statistically significant effects of father's education. The single change in the minimum schooling law, however, prevents the use of cohort-specific trends. As a result, it is impossible to disentangle compulsory schooling effects from cohort effects. Chevalier's sample of children is also confined to those who are still living at home with their parents, and the distribution of educational attainment among children living at home will be different from that in the population. Teenagers who are high school dropouts, for example, are more likely to be living apart from their parents than those who are still in school. While a high proportion of 16 and 17 year-olds still live at home, among those that left school early, that proportion is much lower.

Black, Devereux and Salvanes examine the effects of an increase in mandatory schooling from 7 to 9 years, which was phased in across municipalities in Norway between 1959 and 1973. Using the timing of the law changes to instrument for parental education, they find weak (but not statistically significant) evidence of a causal relationship between parental education and children's outcomes. They do find however, that among mothers with low levels of education, the mandated increase in education had a statistically significant effect on their children's educational attainment. 
The larger variation in compulsory school law changes in the United States, and the larger samples from the U.S. Censuses enable us to arrive at much more precise estimates than from the Norwegian analysis. Institutional differences across countries may also lead to different results. Cross-country comparisons of intergenerational mobility find that Americans exhibit less mobility than most Europeans [Bjorklund et al.(2002); Solon (1999)]. Finally, the Black et al. estimates may be downward biased because all of the children in the sample are subject to the 9 year schooling requirement, whereas only some of the parents are affected by the change in the law. We are able to avoid this because we focus on children's grade retention instead of completed education.

\section{Empirical Strategy}

Let $y_{i f}$ denote a relevant outcome for child $i$ living in family $f$. Suppose that the true model for $y_{i f}$ is

$$
y_{i f}=\alpha+\beta_{1} \text { FathEd }_{f}+\beta_{2} \text { MothEd }_{f}+\beta_{3} X_{f}+\varepsilon_{i f}
$$

where FathEd $_{f}$ and $M o t h E d_{f}$ indicate the educational attainment of the child's father and mother, $X_{f}$ is a vector of all the other family background characteristics that affect the child's outcome, and $\varepsilon_{i f}$ is an error term representing the effects of individual specific factors that are uncorrelated with family background. If we could observe everything that belongs in X then estimates of $\beta_{1}$ and $\beta_{2}$ would capture the effects of parents' educational attainment that are independent of their other characteristics. Because this is not possible, we attempt to address the 
omitted variables problem by using U.S. compulsory school laws as instruments for completed education. Lleras-Muney (2001), Schmidt (1995) and Goldin and Katz (2003) have documented the effectiveness of these laws from 1910 to 1940 , specifically examining the effects of the latest age allowed before requiring school entry, the minimum school leaving age, and the minimum age at which a child could obtain a work permit to exempt her from school. All three studies conclude that these laws had modest, but statistically significant effects on educational attainment. For example, Goldin and Katz (2003) conclude that changes in compulsory school legislation over this 30-year period account for about 5 percent of the more than doubling of secondary school enrollment.

Acemoglu and Angrist (1999) have also collected and recorded information on compulsory schooling laws between 1915 and 1969, and have used them to estimate both individual and social returns to education. They simplify the laws by converting them into two variables: the minimum length of time required in school before being allowed to leave, and the minimum length of time required in school before being allowed to obtain a work permit. While both types of laws were influential, work exemptions often allowed students to leave school before the minimum school leaving age. Several authors have found that the effect of work permits on educational attainment often dominated the effect of school leaving age restrictions. Therefore, our instruments will be based on the minimum number of years of schooling required in order to obtain a work permit and we will use Acemoglu and Angrist's data collection and simplification. ${ }^{5}$ Estimates based on school leaving age restrictions are very similar. ${ }^{6}$ In the following section, we describe more precisely how we utilize their information on the laws.

\footnotetext{
${ }^{5}$ The variables collected by Acemoglu and Angrist, Goldin and Katz, and Lleras-Muney are very similar and yield similar IV estimates. We chose to work with Acemoglu and Angrist's laws because they allowed us to examine parents from a wider range of birth cohorts.

${ }^{6}$ Available from the authors.
} 
We estimate the effect of parents' education simultaneously, as in equation (1), and separately. Since the standard error estimates that are produced when we estimate equation (1) are too large to be able to discern which parent's education affects the child more, our discussion will focus on separate analyses of mothers' and fathers' education, recognizing that the estimated coefficient we obtain for each parent's education will also reflect any benefits to the child that result if more highly educated parents are able to obtain "better" spouses. The results that are produced from our joint estimation of mothers' and fathers' education are discussed in Section V.F.

Instead of estimating the equations at the individual level, we conduct our instrumental variables analysis after aggregating our data to the parental state of birth, parental cohort, and census year level. Aggregating to the state of birth and cohort level explicitly acknowledges that our identifying variation comes from variation in compulsory schooling laws across states and cohorts rather than across individuals. We also aggregate separately by census year because we wish to take into account the fact that our data are derived from three different census years by including census year fixed effects. There are two reasons that we wish to do this. First, each cohort is observed three times: in 1960, 1970 and 1980, and as each cohort ages, their average level of completed education may change. Second, there may be minor differences across survey instruments. $^{7}$

To estimate the instrumental variables counterpart of equation (1), we first generate cell means for all variables in the regression specification. We then estimate the following first-stage regression equations:

\footnotetext{
${ }^{7}$ We have also run individual level regressions, regressions that are based on aggregation to the parental state and year of birth only, and regressions in which the cells are defined by parental state of birth/parental year of birth/census year and child's state of residence. The latter specification allows us to include state fixed effects, which control for differences in educational quality experienced by children across states. These specifications all produce very similar estimates.
} 


$$
\begin{aligned}
& \text { FathEd }_{y j k}=\gamma_{0}+\gamma_{1} C L 7_{j, k+14}+\gamma_{2} C L 8_{j, k+14}+\gamma_{3} C L 9_{j, k+14}+\gamma_{4} X_{y j k}+u_{y}+u_{j}+u_{k}+u_{j k} \\
& \text { MothEd }_{y l m}=\eta_{0}+\eta_{1} C L 7_{j, k+14}+\eta_{2} C L 8_{j, k+14}+\eta_{3} C L 9_{j, k+14}+\eta_{4} X_{y l m}+v_{y}+v_{l}+v_{m}+v_{l m},
\end{aligned}
$$

where $F a t h E d_{y j k}$ represents average father's education level for the group of youths observed in census year $y$, with fathers from state $j$ born in year $k, M o t h E d_{y l m}$ represents average mother's education level for the group of youths who are observed in census year $y$, with mothers from state $l$ born in year $m$, and $X$ is a vector of variables that capture the child group's average race, gender and age. We will estimate both the first and second stage standard errors using Huber-White standard error estimates and clustering by parent's state and year of birth. The instruments to be excluded are CL7, CL8, and CL9 which are dummy variables that denote required years of schooling prior to obtaining a work permit of 7,8 , or 9 or more years. Details of how these variables are coded are given in the data section. Fixed effects are included for the relevant census year, and parent's state and year of birth.

Identifying the effects of the compulsory school laws on parental education is made possible through differences in the timing of the changes in these laws across states. Importantly, there is no reason to expect a future generation's human capital to affect the laws that were imposed on a prior generation. It is also difficult to think of parental characteristics that would be affected by compulsory schooling laws except through the laws' effect on parental education. If compulsory schooling laws were changed in response to other changes in a state such as its demand for low-skilled workers, then they would make poor instruments for estimating contemporaneous wage returns to education, but changes in state characteristics are unlikely to have an effect on children's grade retention some twenty years later.

Lleras-Muney (2001) devotes considerable attention to this issue and finds no evidence that the law changes reflect other factors that might affect parent's education levels. For 
example, she includes measures of manufacturing wages, the percent of workers employed in manufacturing, expenditures on education and a number of demographic characteristics in regressions of educational attainment on compulsory schooling laws and finds that their inclusion does not affect the coefficient estimates on the laws. She also matches individuals to the laws that were in place when they turned 15 through 24 years of age (when the laws should no longer have had an effect), and finds that while current laws are always significant, future laws are virtually never significant. ${ }^{8}$

A related concern is that changes in compulsory schooling laws affect the educational attainment of the adults in the child's state. This might lead to changes in the child's environment beyond her own family background that could affect her eventual outcomes. For example, if more highly educated adults are more likely to support school taxes, and higher school expenditures affect children's human capital then compulsory schooling laws will not allow us to isolate the effect of growing up in a more educated family from the effect of growing up in a more educated community. Fortunately, several findings in the literature suggest that any "spillover" effects of the laws will be small. Goldin and Katz (2003), for example, find that compulsory schooling laws only explain about $5 \%$ of the convergence in educational attainment between 1915 and 1940. In addition, the laws have been shown to have no impact on educational attainment beyond $12^{\text {th }}$ grade. This, combined with the fact that those affected by a change in the law will comprise only a small fraction of the total stock of adults, suggests that changes in compulsory schooling will have minimal affects on the education level of the adults in the child's community. Furthermore, Acemoglu and Angrist (1999) find little evidence that education generates positive externalities (in the form of higher wages).

\footnotetext{
${ }^{8}$ Landes and Solomon (1972) run similar but much sparser regressions for the period 1880-1910 (which is prior to the period we study) using only 10 year leads and find that the laws passed 10 years later were correlated with educational attainment.
} 
Nevertheless, we take the possibility of instrument endogeniety seriously and employ a number of strategies to verify that our compulsory schooling variables are not picking up the effect of other changes in the child's environment. For example, we show that the effect of the laws is experienced exclusively by parents with less than 12 years of education, which reduces the likelihood that they reflect more general state or cohort effects. We also show that our estimates are robust to the inclusion of many state/year controls and to the exclusion of children who reside in the same state in which their parents were born. The details of these analyses are discussed in Sections V.D and V.E.

The following shows our main second-stage regression equations:

$$
\begin{aligned}
& y_{y j k}=\delta_{0}+\delta_{1} \text { FathEd }_{y j k}+\delta_{2} X_{y j k}+\varepsilon_{y}+\varepsilon_{j}+\varepsilon_{k}+\varepsilon_{y j k} \\
& y_{y l m}=\lambda_{0}+\lambda_{1} \text { MothEd }_{y l m}+\lambda_{2} X_{y l m}+e_{y}+e_{l}+e_{m}+e_{y l m}
\end{aligned}
$$

where $y_{y j k}$ is the average child outcome among children in census year $y$, with fathers from state $j$ born in year $k$, and $y_{y l m}$ is defined similarly for mothers.

\section{Data}

\section{IV.A. Census Data}

Our analysis uses data from the Integrated Public Use Microdata Series (IPUMS) created by the Census Bureau. The IPUMS consists of individual and household level data from the decennial census, and includes nearly all of the detail originally recorded by the census enumerations. Information exists at the individual level on a broad range of individual characteristics, including fertility, marital status, immigration, labor-force participation, income, occupational structure, education, ethnicity and household composition. We use the $1 \%$ samples from the 1960, 1970 and 1980 Censuses, which creates for us a dataset of 711,072 children 
living in two parent families and 129,632 children living in single parent families. The size of our dataset is an enormous advantage in terms of enabling us to obtain precise estimates. Most previous studies of intergenerational education effects have been hampered by researchers' reliance on datasets of fewer than 1,000 observations. The main disadvantage of the IPUMS, and the reason that it has not been used for intergenerational mobility studies, is that it is a crosssectional dataset that contains little information on children's outcomes. Typical measures of children's success, such as test scores or behavioral problems are not collected by the census. Measures of longer term outcomes such as wages, labor force participation or teenage childbearing are available in IPUMS, but since many of these attributes are relevant only for individuals who are in their late teens or older, analyses of these outcomes becomes complicated by the fact that older children are more likely to live apart from their family of origin. If an individual is living outside of his parents' household then there is no way to link him up with his relevant family background characteristics.

The IPUMS does contain information on the level of educational attainment obtained by each member of the household. We use this information, together with information on the child's age to determine whether or not she repeated a grade. Grade repetition is both a widespread phenomenon in the United States and is correlated with many, more commonly used, measures of eventual educational achievement. A recent report from the National Longitudinal Study of Adolescent Health, for example, indicates that over 20\% of American adolescents have repeated a grade (Resnick, et.al. 1997), and Feldman (1997) estimates that in many urban districts more than half of all students will be retained. The likelihood of being held back is also highly correlated with family background: in 1995, the probability of being retained was about $40 \%$ higher among young adults from low income families relative to young adults from middle 
income families, and about 50\% higher for blacks compared to whites (National Center for Education Statistics, 1997).

There is also evidence that grade retention is correlated with other measures of children's success. The National Center for Education Statistics (1997) for example, estimates that approximately one quarter of young adults who had repeated a grade had dropped out of school by 1995. Similarly, Smith and Shepard (1989) find that students who have previously repeated a grade tend to have worse academic outcomes than similar students who have not repeated a grade. Since educational attainment and test scores are well known to be predictors of adult earnings and health, these studies suggest that if we can obtain estimates of the causal effect of family income and parental education on the probability that a child repeats a grade, we will also gain insight into the causal relationship between these family background characteristics and children's long-run success.

Determining whether or not a child has repeated a grade is complicated by the fact that there is variation across states and over time in the minimum age at school entry, incomplete information on school entry cut-off dates across states and over time, and questions about the degree to which school districts comply with those dates. ${ }^{9}$ Since we do not have school entry cutoff dates for each state and year, we create two different measures for assessing "normal" educational progress. Our first measure assumes that all states use October 1 as their cut-off date. In other words, we assume that a child who turns six in the first three quarters of the calendar year will enter first grade in the fall of that year, and that a child you turns six in the fourth quarter of the year will enter first grade in the fall of the following year. Our limited

\footnotetext{
${ }^{9}$ We have been able to obtain state level information on minimum school entry ages and cut-off dates for 1955 and 1965: 43 states in 1955 and 32 states in 1965. Twenty two states maintained the same cutoff dates over the ten year period and 7 states changed their cutoff-date. Missing information prevents us from determining what happened in the remaining states.
} 
information on school entry cutoff dates in 1955 and 1965 indicates that he vast majority of states invoked cutoff dates between September 1 and November 1. The Census provides information on age at the time of the survey, quarter of birth and enumeration date. From this data it is straightforward to determine the year and quarter in which a child was born. We assign a value of 1 to the variable REPEAT if the child's reported years of completed schooling is less than the number of years he "should" have completed based on the Oct 1 cutoff date and 0 if the child is on target or ahead.

Our second measure classifies children whose educational attainment is below the median for their state, age, quarter of birth, and census year cell as repeaters. In other words, we estimate the number of years a child "should" have completed based on the median grade reached among those who are the same age, and were born in the same birthquarter, live in the same state, and were observed in the same census year. Any child below the median is then classified as having repeated a grade. Thus, our second dependent variable, $<$ MEDIAN-GRD, is equal to 1 if a child's grade is below the median for other corresponding children, and 0 otherwise. We think that $<$ MEDIAN-GRD is a cleaner measure of whether or not a child has repeated a grade because it takes into account state and individual level characteristics that affect the age at which the child was likely to have enrolled in school. Because individuals' completed education levels are heavily clustered at the median, about $10-15 \%$ of children in each cell are below the median. These percentages are similar to the percent of those who are classified as having repeated using the REPEAT measure.

Neither of these measures is perfect. Students who entered school late, for example, will be classified as having been held back, and delayed entry into kindergarten is a fairly common practice. Nine percent of first and second graders in the mid-1990's had entered kindergarten 
late, whereas only 5-6\% had repeated kindergarten (National Center for Education Statistics, 2000). In a recent paper, Cascio (2003) compares directly reported measures of grade repetition in the 1992, 1995 and 1999 Current Population Survey School Enrollment Supplement to a below grade proxy created using educational attainment data available in the Census. She finds that about $20 \%$ of all children are incorrectly classified by the below grade proxy, and that about 94\% of such errors are comprised of children who have not repeated a grade but who are classified as such by the proxy.

Normally, researchers are not concerned that noisy dependent variables will generate biased estimates because measurement error in a normally distributed dependent variable merely generates inefficient standard error estimates. Cascio points out, however, that when the dependent variable is an indicator for whether or not the individual has repeated a grade, then consistency may be a problem. Measurement error in a binary dependent variable will produce attenuated parameter estimates (Aigner, 1973; Hausman, 2001). Cascio estimates that the attenuation factor that results from using dependent variables like our REPEAT and $<$ MEDIANGRD may be as high as 0.35 . While we would prefer to generate unbiased estimates, downward biased estimates will still be informative because our prior is that the intergenerational correlation captures effects that are not wholly causal. Therefore, estimates that are statistically different from zero will still allow us to reject the hypothesis that there is not an exogenous effect of parental education on children's human capital. Also, although $<$ MEDIAN-GRD is binary, it is a less noisy variable than REPEAT because it takes into account variation in state, age and quarter of birth by normalizing attainment within each cell. Specifications based on this measure, therefore, should suffer less from attenuation bias than those based on REPEAT. 
The analysis focuses on children between the ages of 7 and 15 years of age. Children younger than age 7 are not included because they are not old enough to have had the opportunity to repeat a grade. We exclude children older than age 15 in order to avoid over-representing children that left home at late ages. To adjust for the fact that older sample members have had more of an opportunity to repeat a grade, and to adjust for possible gender differences in grade repetition, all of our regressions include controls for age and gender. Summary statistics for our samples are shown in Appendix Table 1.

\section{IV.B. Compulsory Schooling Laws}

Our compulsory schooling data have been previously collected by Acemoglu and Angrist, and by Lleras-Muney. Lleras-Muney's collection of compulsory schooling data is available at http://www.princeton.edu/ alleras/papers.htm. The Acemoglu and Angrist data we utilize are summarized in more detail in their appendix. As noted above, we follow earlier authors by using a variable designed to capture the minimum number of years of schooling that would be required before an individual is eligible for a work permit. Specifically, we use the following variable to instrument for education:

$C L=\max \{$ required years of schooling before receiving $a$ work permit; minimum age required for a work permit-enrollment age\}

In order to capture a potentially non-linear relationship between years of schooling required and educational attainment, we use the CL variable to create dummy variables of the form:

CL6 $=1$ for $\mathrm{CL} \leq 6$, and 0 otherwise

$\mathrm{CL} 7=1$ for $\mathrm{CL}=7$, and 0 otherwise 
$\mathrm{CL} 8=1$ for $\mathrm{CL}=8$, and 0 otherwise

CL9 $=1$ for $\mathrm{CL} \geq 9$, and 0 otherwise

These dummies are matched to parents in our sample based on the school entry laws that were in place in their state of birth when they were 6 years old and the school leaving laws that were in place when they were 14 years old. We chose these as the relevant matching years because they are the lowest common entry and leaving ages across states. Although we would prefer to match according to the parents' state of residence at ages 6 and 14, that information is not available in the Census, which is our primary source of data. This inevitably leads to some mismatches, but the resulting errors are unlikely to be correlated with the laws because the laws were not likely a motivating factor behind cross-state moves. Over $90 \%$ of parents in our sample faced 6 to 9 years of mandatory compulsory schooling.

\section{Results}

\section{V.A. First-stage Results}

Before turning to our 2SLS estimates, we examine the results produced by the first stage. Table 1 shows that compulsory schooling laws changed frequently both across states and within states over time. ${ }^{10}$ For example, in 1940 there were 7 states that required seven or fewer years of schooling, four states that required exactly eight years of schooling and 26 states that required nine years. Moreover, between 1915 and 1970, required years increased to more than seven in 29 states while 24 states increased the required number of years to more than 10 . About $1 / 3$ of the variation in the laws is across-states and about $2 / 3$ is within states over time.

\footnotetext{
${ }^{10}$ The table includes the number of states that are included in our sample for each year. We are missing compulsory schooling data for Alaska and Hawaii. The table omits additional states in a few years because our sample of children does not always include a match with a particular parental state/year cell.
} 
Table 2 provides the coefficient estimates from the estimation of equations 2 and 3 , along with the partial $\mathrm{R}^{2}$ and the F-statistic for the hypothesis that the compulsory schooling laws are jointly equal to zero. Looking first at the relationship between the laws and married fathers' educational attainment, we see that the coefficient estimates on the compulsory schooling dummies increase monotonically as expected and are all statistically significant. Importantly, given our goal of using this relationship as the basis for instrumental variables estimation, the Fstatistic for the full sample of married fathers on the joint test of instrument significance is 46 . Bound, Baker and Jaeger (1995) have suggested that one should be concerned about the possibility of weak instrument bias when F statistics are close to 1. Staiger and Stock (1997) further suggest that a value of less than 5 could signal weak instruments. Our F-statistic suggests that the instruments are strongly correlated with the endogenous regressor, which gives us some confidence that our IV estimates are unlikely to suffer from bias due to weak instruments. The partial $\mathrm{R}^{2}$ on the instruments is 0.004 . This is an order of magnitude greater than the first-stage partial $\mathrm{R}^{2}$ which generated concern by Bound Baker and Jaeger.

For more evidence that the compulsory schooling laws are affecting parental education in the expected way, we separate the sample on the basis of the parents' completed education level. Since compulsory schooling laws never mandate high school completion, we do not expect the law changes to have an affect on educational attainment beyond high school. The relationship that we see for the full sample in Table 2 should break down when looking at only those with more than a high school education. For the subsample of children whose fathers' highest level of education was a high school diploma or less, all of the relevant statistics look much the same as in column 1. Among children whose parents received some post-secondary schooling, however, the compulsory schooling dummies show no evidence of being correlated with higher levels of 
educational attainment. The partial $\mathrm{R}^{2}$ on the instruments is smaller than for less educated parents, and the F-statistic has a value of 4 . This suggests that compulsory schooling laws are not picking up more general state-level changes in educational attainment. ${ }^{11}$

The first-stage estimates for mothers in two parent families and heads in single parent families look very similar to those for fathers. For both types of parents, the point estimates on the compulsory schooling dummies suggest that more required years of schooling is positively correlated with higher educational attainment. This pattern is repeated among less educated parents, but does not hold among more highly educated parents. In addition, the partial $\mathrm{R}^{2}$ range from .007 to .011 for both the full samples and the samples of less educated parents, but are much smaller for the samples of highly educated parents. Likewise, the F-statistic is large for the combined sample and for the less educated sample, but falls to 2 when the sample is confined to parents with some post-secondary education. Taken together, these first-stage estimates suggest that compulsory schooling laws are strongly correlated with the levels of educational attainment that one would expect.

\section{V.B. Reduced Form Results}

Table 3 provides the reduced form results from regressing children's educational progress on the compulsory schooling dummies. The first-stage effects of the minimum school leaving age faced by the parents are strong enough to observe a substantive reduced form effect on children's grade repetition. Children whose fathers were required to stay in school for 7 years

\footnotetext{
${ }^{11}$ We leave out those children whose parents have exactly 12 years of education because it is unclear how we would expect the education levels of these parents to have been affected by the change in the laws. On the one hand, since the laws do not ever mandate that an individual complete high school, we would expect the laws to have minimal explanatory power among parents with 12 or more years of schooling. On the other hand, individuals obliged to continue high school may perceive the costs of graduation to be smaller than if they could have left school earlier, and may, therefore, decide to stay on until they obtain a degree. When we conduct our analyses by education category but include the parents with exactly 12 years of schooling our results are similar to those we present here.
} 
were 1.5 percentage points less likely to repeat a grade, on average, than those whose parents faced more lenient schooling requirements. The pattern of the estimates is also in keeping with what one would expect: children whose parents were required to stay in school more years generally experienced larger human capital gains. This pattern is similar when we use the work permit laws faced by married mothers and single parents.

\section{V.C. OLS Results}

The next table displays estimates produced by Ordinary Least Squares (OLS) regressions of equation (1). Across all parental types and education categories, parental education is strongly significantly related to children's human capital accumulation. In general, the point estimates suggest that an additional year of education will reduce the probability that a child repeats a grade by 3 to 4 percentage points. The marginal effect of education is smaller among more highly educated parents, suggesting that the intergenerational return to education falls as education increases, but the estimates are still substantive and statistically significant. These results are consistent with the existing literature, which has documented a positive intergenerational correlation between parents' education and that of their offspring. What is unclear is the extent to which these estimates reflect a causal relationship. To what degree can parents improve their children's progress through school by investing in their own human capital? This question is addressed by our IV estimates in the following section.

\section{V.D. Two-stage Least Squares Results}

The estimates presented in Table 5 are generated when compulsory schooling laws are

used as instruments for parental education. Regardless of which definition of educational 
progress is used, the IV estimates indicate that an increase in parental education will lower the probability that a child is held back in school. The point estimates suggest that raising mother or father's education by one year (about a third of a standard deviation) will reduce the probability of their children being retained by between 3 and 8 percentage points. The estimates are all statistically significant at the 1 percent level.

Like previous work that uses compulsory schooling laws as instruments, the IV estimates are larger than the corresponding OLS estimates. ${ }^{12}$ Some researchers have argued that this phenomenon occurs because errors-in-variables biases outweigh omitted variables biases in OLS regressions. Another explanation is that compulsory schooling laws affect schooling levels at the bottom of the education distribution but not at the top. The marginal effect of an additional year of schooling is likely to be larger among those with low skill levels, and Angrist, Imbens and Rubin (1996) note that IV estimates will reflect the marginal return for the group that is affected by the instrument. The pattern of the OLS estimates across education groups is consistent with this possibility, with the estimated correlations between parental education and children's outcomes being two to four times greater among children with less educated parents than among children whose parents have more than twelve years of education. ${ }^{13}$

The next panel of Table 5 shows the results from IV regressions applied to the subset of children whose parents have less than 12 years of education. The evidence presented above on the power of the first-stage regressions suggests that the IV strategy is most appropriate for this restricted sample, since our instrument has very low power among parents with more than 12 years of education. As expected, these estimates are similar to the estimates generated by the full

\footnotetext{
${ }^{12}$ The confidence intervals around the OLS estimates do not include the IV estimates, and vs. versa. Hausman tests for equality of the OLS and IV estimates also reject the null of equality, but this test may not be appropriate since we are using clustered data.

${ }^{13}$ Of course, if there are omitted variables then the information provided by OLS estimates must be regarded with caution.
} 
sample, although they are no longer statistically significant for children growing up in singleparent families when using the $<$ MEDIAN-GRD measure.

The last column of Table 5 presents the results from IV regressions that use the log of parental wages as the dependent variable. ${ }^{14}$ We present these estimates in order to show that they are very similar to those produced by Acemoglu and Angrist (1999), who use the same instruments to estimate wage returns to education. For example, we find that the wage return to an additional year of father's education is about $12 \%$, which compares favorably to Acemoglu and Angrist's estimate of $8 \%$. The estimated returns for married women and single parents are somewhat higher. Acemoglu and Angrist confine their analysis to men. ${ }^{15}$

While not directly comparable because of differences in the dependent variables, our estimates appear to be slightly smaller and more precisely estimated than those produced by Black, Devereux and Salvanes, who find that an additional year of parental education will raise the child's education by .04 to .11 of a year but whose estimates are not generally statistically different from zero. If we assume that grade-repetition will translate less than one-for-one into differences in completed schooling, our point estimates imply substantially smaller effects. As noted above, the fact that our estimated effects are statistically significant (despite their smaller magnitudes), may reflect the greater amount of variation in compulsory schooling laws in our sample, relative to the Black, el al. sample. Another difference between our study and theirs is

\footnotetext{
${ }^{14}$ We eliminate parents with zero wages or income.

${ }^{15}$ We also measured educational progression as the relative difference between a child's actual grade and the median grade of that child's age, quarter of birth, stage, and census year group. In these regressions, which are not shown, the estimated coefficients suggest that increasing father's education by one year will increase his child's years of schooling-for-age by 0.02 of a year and that increasing mother's education by one year will raise her child's years of schooling-for-age by 0.01 . These coefficients are much less precisely estimated than when we use REPEAT and $<$ MEDIAN-GRD, however, probably because variation in the residual reflects variation at both the upper and lower tails of the distribution of education. Forcing parents to complete another year of high school may have an affect on the probability that the child repeats a grade, but no effect on the probability that the child completes a grade ahead of schedule. The estimated effect of father's education is statistically different from zero at the $1 \%$ level, but the estimated effect of mother's education is not statistically significant at any usual confidence level.
} 
that Black et. al. also consistently report IV estimates that are below their OLS estimates. Two possible explanations are that 1) measurement error in the Norwegian education data is likely very small because the data come from an administrative source, and 2) returns to education do not differ greatly across segments of the Norwegian population

Since grade repetition and educational-attainment-for-age are not typical dependent variables, we have also used our instruments to estimate the effect of parental education on the probability that a child drops out of school. Using census data on 15-18 year olds living at home, we construct a variable that is equal to one if the child is not currently enrolled in school and has not completed 12 or more years of schooling, and we create the same measure for a sub-sample of 15-16 year olds. Because the census files only allow us to look at outcomes for children while they are in the same household as a parent, the high school drop-out variable is not ideal: dropping out of school is likely to be correlated with moving out of a parents' household. As a result, the analysis will suffer from selection bias. Despite this concern, we present some results using dropout status as our dependent variable, with the caveat that the effects shown here cannot be generalized to the entire population of 15-18 year olds. Selection issues may be less severe for the sample of 15-16 year olds. ${ }^{16}$

The results from this exercise are presented in Table 6. Across all samples, and regardless of the measure of parental education used, there is a negative and (with one exception) statistically significant relationship between parents' education and the probability of dropping out of high school. As with our analysis of grade repetition, the IV estimates are larger in absolute value than the OLS estimates, and suggest a significant causal relationship running from parental education to children's educational attainment. Among 15-18 year olds, these estimates

\footnotetext{
${ }^{16}$ Roughly $95 \%$ of 15 year olds in the Census live with at least one parent, but only $77 \%$ of 15 year-old high school dropouts live with a parent. At age 17, these fractions fall to $88 \%$ of all 17 year olds, and $67 \%$ of 17 year old dropouts.
} 
suggest that an additional year of parental education reduces the probability of dropping out by 3 to 5 percentage points. The mean drop-out rate for this sample is .07 among two parent households, and .13 among single parent households. There is also evidence that sample selection affects the estimates. The coefficient estimates fall (in absolute value) substantially when we limit the sample to 15 and 16 year olds, who are more likely to be observed living with a parent. This might be expected if children not living with their parents are also less influenced by parental characteristics and resources.

Finally, the magnitudes of the effects on drop-out rates are sensible given our estimates on grade repetition. As noted above, the National Center for Educational Statistics reports that roughly a quarter of those repeating grades eventually dropped out of high school. Our results for 15 and 16 year olds suggest effects on the drop-out rate that are roughly one-quarter the size of the effects on grade retention. The estimated effects on the drop-out rate are large, relative to the sample mean drop-out rates. It seems likely, however, that typical drop-out rates among children whose parents were affected by compulsory schooling laws may be substantially higher. The average drop-out rate among children of fathers with less than a high school education, for example, is .12, compared with .07 for the full sample. While we do not wish to draw any strong conclusions from the drop-out analysis given the sample selection issues involved, the results in Table 6 are consistent with those produced by our main analysis. Higher parental education appears to result in improved educational outcomes for children.

\section{V.E. Further Investigation of Instrument Exogeneity}

An important set of concerns with our identification strategy is that the instruments may be correlated with other state-level changes that affect children's progress through school. 
It is important to remember that since the relevant compulsory schooling laws pertain to the year that the parent turned 14, such state-level changes would have to have an effect on children's outcomes approximately twenty years later. We have also demonstrated that compulsory schooling laws only affect educational attainment among parents with low skills, which suggests that they are not picking up a more general state trend. Nevertheless, in this section we devote our attention to a number of additional robustness checks.

First, we add a variety of state-year controls to our regressions. The additional variables are motivated by Lleras-Muney (2001) who explicitly explores the possibility that compulsory schooling laws are endogenous with respect to educational attainment, and include the state population, the number of schools per square mile, the number of doctors per capita, the value per acre of farm land, the percent of the state population that is foreign born, the fraction of the state population living in urban areas, the fraction who are manufacturing workers, and average wages per worker. The results from this exercise are displayed in the Table 7. Inclusion of the state/year controls has virtually no effect on the estimated effect of parental education and the First-stage F-statistics remain strong. ${ }^{17}$ In the next column we include regional trends along with the additional control variables. The inclusion of the regional trends has virtually no impact on the estimated effect of father's education, but it does reduce the estimated coefficient on mother's education when the dependent variable is <MEDIAN-GRD, and it is no longer statistically different from zero.

We have also estimated our regressions with state-specific trends, but we find that this greatly reduces the first-stage power of our excluded instruments. It is thus not possible to separately identify the effects of the state-specific timing of compulsory schooling law changes

\footnotetext{
${ }^{17}$ The estimated coefficients in the single-parent sample are hardly affected by the inclusion of state controls, but the estimated standard error increases so that the statistical significance of the estimates is reduced.
} 
from the effects of other, unobserved state-specific trends. Perhaps this should not be surprising given that over the period we study most states experienced both upward trends in educational attainment and increases in compulsory schooling requirements. We note, however, that in order for our IV estimates to be biased unobserved state trends would have to be correlated with educational outcomes for children that are observed many years later, and often in different states (35\% of our children do not reside in their parent's state of birth). We also note that the estimated coefficients produced by IV regressions that include state trends are very similar to those that were previously reported, but that their accompanying standard error estimates are much larger.

Another way of exploring the possibility that our results are driven by unobserved state trends is to replicate our analysis using only the subset of states and periods for which there was a decrease in the minimum required years of schooling. We, therefore, create a subsample that includes all state/year cells from five years prior to a decline in the minimum schooling requirement through the five years following the law change. ${ }^{18}$ Like the rest of the country these states experienced a positive trend in average educational attainment in spite of the fact that their compulsory schooling requirements were falling, but because their compulsory schooling laws are moving in the opposite direction, the IV estimates for this sample are less likely to be driven by underlying trends that affect educational attainment. Table 8 shows that restricting the sample in this way has virtually no effect on the estimates, although the estimates for children in single-parent families are no longer statistically significant in the $<$ MEDIAN-GRD specification.

Next, we compare estimates across samples that include different subsets of years during which the parent turned age 14. If the law changes affect only particular periods, then some

\footnotetext{
${ }^{18}$ If a state experienced an increase in required years of schooling during the five year period after the initial law change then it is dropped from the sample. If a second decline in required years occurred during the five year period then the state is included in the sample.
} 
other period-specific event may be behind the identifying variation. For brevity, we focus only on the estimates for $<$ MEDIAN-GRD. The results presented in Table 9 look remarkably similar across the different cohorts, with estimates of the effect of each parent's education level ranging between 4 and 7\%. Furthermore, there is no apparent trend in the magnitude of the estimates over time.

Finally, we estimate the effect of parental education on children's human capital using a sample that excludes children who are living in the same state in which their parents were born. What is nice about this sample of "movers" is that even if unobserved factors in the parent's state of birth influenced the parent's education decision they will not be related to the current educational environment in the child's state. The results from this exercise are shown in the first column of each panel in Table 10 and are very similar to those for the full sample. We can also restrict our identifying variation even further by including interactions between the parent's age and current state of residence. ${ }^{19}$ This leaves us with only cross-sectional variation in compulsory schooling laws and removes any remaining possibility that the estimated effects of parental education reflect unobserved within parental-state-of-birth changes over time. By comparing the estimates produced by this very restrictive specification to those in columns 1 and 3 , we can compare estimates using purely cross-sectional variation to those combining cross-sectional and time-series variation. A finding that these two different sources of identification produce similar results should help to alleviate concerns about instrument exogeneity.

In fact, although this restriction reduces the estimates substantially, they are still statistically different from zero, and suggest that a one year increase in parental education will reduce the probability of repeating a grade by approximately two percentage points. The smaller estimates may indicate that some of our identification is, indeed, coming off of state trends and

\footnotetext{
${ }^{19}$ In order to include state of residence dummies, we run these regressions at the individual level.
} 
that the "true" effect of parental education is somewhat lower than the previous tables suggest. Nevertheless, it is striking that we continue to find a positive and statistically significant effect whether our identification is confined to cross-sectional or time-series variation.

\section{V.F. Simultaneous Estimation of Mothers' and Fathers' Education Effects}

Our analyses so far have focused on the relationship between one parent's education and her child's human capital, but an advantage of our data is that we have information on each parent's educational attainment. In principle, therefore, we can test the hypothesis that mothers' education is more influential than fathers' and vs. versa. Previous authors have speculated that because mothers and fathers tend to form different types of relationships with their children, the effect of their relative education levels may also be quite different. Behrman and Rosenzweig, for example, find no evidence that the level of mother's education has a positive effect on her child's outcome but do find evidence that more highly educated fathers tend to raise more highly educated children. One explanation for their finding is that more highly educated women are less likely to stay home, which may have a detrimental affect on their children's development. Although the estimates presented in the previous tables are based on regressions that include only one parent's level of education, they represent the combined effect of each parent's education together with any effect that results from assortative mating. In order to determine the relative importance of each parent's education level one must include them in the same regression.

Table 11 shows how the estimates of parental education are affected when mother's and father's education are included in the same equation. We find that the combined estimates on each parent's education are about the same as when they are estimated separately and that the 
estimates are always jointly significant. The standard error estimates are much higher, however, and the estimates are not individually significantly different from zero or from each other. This is not surprising since our identification strategy rests on variation across states and over time, and mothers and fathers are often close in age and from the same state. Unfortunately, the imprecision of the estimates means that it is impossible to say anything about each parent's relative importance in the transmission process.

\section{Conclusion}

This paper provides new evidence on the causal effect of parental education across generations. The limited literature on the intergenerational effects of parental education has struggled to find appropriate identification strategies; we draw on variation in compulsory schooling laws, which are arguably exogenous with respect to children's outcomes fifteen or more years later. Using data from the 1960-1980 Census files, we estimate that an increase in parental education of one year will reduce a child's probability of being retained by between 2 and 7 percentage points. Since grade retention is negatively correlated with other academic outcomes, the positive effect of parental education on children's grade progression is likely to have long-term socio-economic benefits as well.

Identification of a causal effect of parental education implies that at least some of the intergenerational transmission of inequality can be attributed to environmental influences. There are many ways in which higher levels of parental education might affect a child's environment, including increases in family income, better parenting, and improved social networks. Understanding the mechanism by which parental education increases children's human capital is an important question that deserves further research. Nevertheless, our results are encouraging, 
as they suggest that government intervention may be able to play a role in altering intergenerational immobility. Specifically, knowing that there are intergenerational returns to increased schooling provides a further rationale for programs that provide educational assistance.

More generally, our results draw attention to the social externalities that are associated with education. While much research has been devoted to understanding the private returns to education via individual wage effects, designing effective education policy hinges crucially on taking the full social costs and benefits into account. There is increasing evidence that the social returns to education are substantial ${ }^{20}$ and our estimates suggest yet another dimension along which positive externalities occur. Taken together, these findings indicate that the total returns to education may be seriously underrepresented by estimates that focus only on individual wage effects.

\footnotetext{
${ }^{20}$ Currie and Moretti, 2002; Moretti, 2003; Lochner and Moretti, 2001.
} 


\section{References}

Acemoglu, Daron and Joshua Angrist, "How Large are the Social Returns to Education? Evidence from Compulsory Schooling Laws," National Bureau of Economic Research Working Paper \#7444, December 1999.

Aigner, Dennis J., "Regression with a Binary Dependent Variable Subject to Errors of Observation," Journal of Econometrics, 1 (1): 49-59. (1973)

Angrist, Joshua D. and Alan B. Krueger, "Does Compulsory School Attendance Affect Schooling and Earnings?” Quarterly Journal of Economics, 106(4), November 1991..

Angrist, Joshua D., Guido W. Imbens and Donald B. Rubin, "Identification of Causal Effects Using Instrumental Variables,” Journal of the American Statistical Association, June 1996.

Antonovics, Kate, and Arthur S. Goldberger, "Do Educated Women Make Bad Mothers? Twin Studies of the Intergenerational Transmission of Human Capital” Mimeo, 2003.

Behrman Jere R., and Mark R. Rosenzweig "Does Increasing Women's Schooling Raise the Schooling of the Next Generation?" American Economic Review, 92:1, March 2002, 323-334.

Behrman, Jere R., Mark R. Rosenzweig, and Paul Taubman, "Endowments and the Allocation of Schooling in the Family and in the Marriage Market: The Twins Experiment," Journal of Political Economy, 102 (6), 1994, pp. 1131-74.

Bjorklund, A., M. Jantii, O. Raaum, E. Osterback, and T. Eriksson, "Brother Correlations in Earnings in Denmark, Finland, Norway and Sweden Compared to the United States," Journal of Population Economics, Vol. 15, 2002, pp. 757-772.

Black, Sandra, Paul J. Devereux, and Kjell G. Salanes "Is Education Inherited? Understanding Intergenerational Transmission of Human Capital.” Mimeo, UCLA, 2003.

Bound, John, David A. Jaeger, and Regina Baker, "Problems with Instrumental Variables Estimation when the Correlation Between the Instruments and the Endogenous Explanatory Variables is Weak," Journal of the American Statistical Association, June 1995, 90(430), 443-50.

Bound, John, and David A. Jaeger, "On the Validity of Season of Birth as an Instrument in Wage Equations: A Comment on Angrist and Krueger's "Does Compulsory School Attendance Affect Schooling and Earnings"," NBER Working Paper 5835, November 1996.

Cascio, Elizabeth, "School Progression and the Grade Distribution of Students: A Validation Study Using the Current Population Survey," mimeo, June 2003. 
Chevalier, Arnaud, "Parental Education and Child's Education: A Natural Experiment," mimeo, University College Dublin. 2003.

Currie, Janet and Enrico Moretti, “Mother's Education and the Intergenerational Transmission of Human Capital: Evidence from College Openings and Longitudinal Data," working paper, August 2002.

Feldman, S. "Passing on Failure,” American Educator, 21(3), Fall 1997, 4-10.

Griliches, Zvi. "Sibling Models and Data in Economics: Beginnings of a Survey." Journal of Political Economy. Part 2, October 1979; 87(5):S37-64.

Goldin, Claudia and Laurence Katz, "Mass Secondary Schooling and the State: The Role of State Compulsion in the High School Movement," mimeo, Harvard University, 2003.

Harmon, Colm and Ian Walker, "Estimates of the Economic Return to Schooling for the United Kingdom,” American Economic Review, December 1995, pp. 1278-86.

Hausman, Jerry, "Mismeasured Variables in Econometric Analysis: Problems from the Right and Problems from the Left." Journal of Economic Perspectives, 15 (4): 57-68.

Landes, William and Lewis C. Solomon, "Compulsory Schooling Legislation: An Economic Analysis of Law and Social Change in the Nineteenth Century," Journal of Economic History, March 1972.

Lleras-Muney, "Were Compulsory Attendance and Child Labor Laws Effective? An Analysis From 1915 to 1939," National Bureau of Economic Research Working Paper 8563, October 2001.

Lleras-Muney, "The Relationship Between Education and Adult Mortality in the United States," National Bureau of Economic Research Working Paper 8986, June 2002.

Lochner, Lance and Enrico Moretti, "The Effect of Education on Crime: Evidence from Prison Inmates, Arrests, and Self-Reports," National Bureau of Economic Research Working Paper 8605, 2001.

Moretti, Enrico, "Human Capital Externalities in Cities," Handbook of Regional and Urban Economics, North Holland-Elsevier, forthcoming, 2003.

National Center for Education Statistics, "Dropout Rates in the United States," NCES research paper, No. 97-473, 1995.

Oreopoulos, P., "Do Dropouts Drop Out Too Soon? Evidence Using Changes in School Leaving Laws," Mimeo, University of Toronto, 2003. 
Resnick, M.D., Bearman, P.S., Blum, R.W., Bauman, K.E., Harris, K.M., Jones, J., Tabor, J., Beuhring, T., Sieving, R., Shew, M., Irreland, M., Bearinger, L.H., Udry, J.R., "Protecting Adolescents from Harm: Findings from the National Longitudinal Study on Adolescent Health," Journal of the American Medical Association, September 10 1997, 278: 823-832.

Rosenzweig, Mark R. and Kenneth I. Wolpin, "Are There Increasing Returns to the Intergenerational Production of Human Capital? Maternal Schooling and Child Intellectual Achievement," Journal of Human Resources, 29:2, Spring 1994, 670-693.

Sacerdote, Bruce “The Nature and Nurture of Economics Outcomes," Mimeo, August 30, 2000.

Schmidt, Stefanie, "School Quality, Compulsory Education Laws, and the Growth of American High School Attendance, 1915-1935,” MIT Ph.D. Dissertation 1996.

Smith, M.L. and L. Shepard, eds., Flunking Grades: Research and Policies on Retention, 1989, New York, Falmer Press.

Solon, Gary, "Intergenerational Mobility in the Labor Market," Chapter 29 in Handbook of Labor Economics, Vol. 3A, Ashenfelter, O. and D. Card (eds.), North Holland Press, 1999, Amsterdam, Netherlands.

Staiger, Douglas and James H. Stock, "Instrumental Variables Regression with Weak Instruments," Econometrica, 65 (3), May 1997. 
Table 1

State Mandatory Schooling Laws by Year

\begin{tabular}{ccccc}
\hline \hline & \multicolumn{5}{c}{ Number of States with Mandatory Years of: } \\
& $<7$ years & $<8$ years & $\begin{array}{c}\text { Total States } \\
\text { observed }\end{array}$ \\
\cline { 2 - 5 } 1915 & 32 & 46 & 47 & 47 \\
1920 & 30 & 47 & 47 & 47 \\
1925 & 15 & 33 & 48 & 49 \\
1930 & 14 & 29 & 48 & 49 \\
1935 & 9 & 21 & 48 & 49 \\
1940 & 7 & 21 & 47 & 49 \\
1945 & 7 & 21 & 47 & 49 \\
1950 & 5 & 15 & 34 & 49 \\
1955 & 3 & 15 & 32 & 49 \\
1960 & 4 & 12 & 31 & 49 \\
1965 & 3 & 11 & 29 & 41 \\
1970 & 3 & 9 & 23 & 49 \\
\hline \hline
\end{tabular}


Table 2

First Stage: Effects of Compulsory Schooling Laws on Parents' Education

\begin{tabular}{|c|c|c|c|c|c|c|c|c|c|}
\hline \multirow{3}{*}{$\begin{array}{l}\text { Years of schooling required } \\
\text { before work permit }\end{array}$} & \multicolumn{9}{|c|}{ Dependent Variable: Parents' Highest Grade of Schooling: } \\
\hline & \multicolumn{6}{|c|}{ Dual Parent Families } & \multicolumn{3}{|c|}{$\begin{array}{c}\text { Single Parent Families } \\
\text { Heads }\end{array}$} \\
\hline & all & $<12$ th Grade & $>12$ th Grade & all & $<12$ th Grade & $>12$ th Grade & all & $<12$ th Grade & $>12$ th Grade \\
\hline 7 years & $\begin{array}{c}0.205 \\
(0.043)\end{array}$ & $\begin{array}{c}0.204 \\
(0.039)\end{array}$ & $\begin{array}{c}0.045 \\
(0.030)\end{array}$ & $\begin{array}{c}0.206 \\
(0.040)\end{array}$ & $\begin{array}{c}0.202 \\
(0.042)\end{array}$ & $\begin{array}{c}0.033 \\
(0.029)\end{array}$ & $\begin{array}{c}0.282 \\
(0.080)\end{array}$ & $\begin{array}{c}0.123 \\
(0.075)\end{array}$ & $\begin{array}{c}0.185 \\
(0.074)\end{array}$ \\
\hline 8 years & $\begin{array}{c}0.312 \\
(0.038)\end{array}$ & $\begin{array}{c}0.280 \\
(0.038)\end{array}$ & $\begin{array}{l}-0.025 \\
(0.027)\end{array}$ & $\begin{array}{c}0.298 \\
(0.035)\end{array}$ & $\begin{array}{c}0.303 \\
(0.038)\end{array}$ & $\begin{array}{l}-0.006 \\
(0.026)\end{array}$ & $\begin{array}{c}0.464 \\
(0.072)\end{array}$ & $\begin{array}{c}0.348 \\
(0.067)\end{array}$ & $\begin{array}{c}0.029 \\
(0.064)\end{array}$ \\
\hline 9 years & $\begin{array}{c}0.524 \\
(0.050)\end{array}$ & $\begin{array}{c}0.496 \\
(0.051)\end{array}$ & $\begin{array}{c}0.017 \\
(0.036)\end{array}$ & $\begin{array}{c}0.510 \\
(0.044)\end{array}$ & $\begin{array}{c}0.439 \\
(0.046)\end{array}$ & $\begin{array}{c}0.031 \\
(0.033)\end{array}$ & $\begin{array}{c}0.733 \\
(0.085)\end{array}$ & $\begin{array}{c}0.547 \\
(0.085)\end{array}$ & $\begin{array}{c}0.085 \\
(0.081)\end{array}$ \\
\hline Initial Sample Size & 711,072 & 711,072 & 711,072 & 711,072 & 711,072 & 711,072 & 129,771 & 129,771 & 129,771 \\
\hline \multicolumn{10}{|l|}{ Cell Mean Sample Size } \\
\hline Adj. R2 & 0.890 & 0.809 & 0.454 & 0.845 & 0.753 & 0.472 & 0.688 & 0.552 & 0.248 \\
\hline Adj. R2 without instruments & 0.886 & 0.802 & 0.45 & 0.837 & 0.742 & 0.472 & 0.681 & 0.544 & 0.247 \\
\hline F-Test: Instruments $=0$ & 46.4 & 34.4 & 3.9 & 59 & 36.9 & 1.5 & 32.2 & 19.6 & 2.2 \\
\hline
\end{tabular}

Notes: All regressions include fixed effects for parent's birth year, state of birth, and census year. Additional controls include race, gender age, and asian ethnicity. Data are grouped into means by parent's birth year, state of birth, and census year, and weighted by cell population size. Huber-White standard errors are shown from clustering by birth cohort and state of birth. The ommited compulsory school law variable indicates whether the minimum years of schooling required before able to obtain a work permit was 6 or less. Samples include all children aged 7 to 15 with U.S. born parents aged 14 between 1915 and 1969 . Standard errors are in parenthesis. See text for more data specifics. 
Table 3

Reduced Form Effects of Parents' Compulsory Schooling Laws on Children's Educational Attainment

\begin{tabular}{|c|c|c|c|c|c|c|}
\hline \multirow{5}{*}{$\begin{array}{l}\text { Years of schooling required } \\
\text { before work permit }\end{array}$} & \multicolumn{6}{|c|}{ Education Attainment of: } \\
\hline & \multicolumn{2}{|c|}{ Fathers } & \multicolumn{2}{|c|}{ Mothers } & \multicolumn{2}{|c|}{ Single Parents } \\
\hline & \multicolumn{6}{|c|}{ Dependent Variable: } \\
\hline & & $<$ MEDIAN & & $<$ MEDIAN & & $<$ MEDIAN \\
\hline & REPEAT & GRD & REPEAT & GRD & REPEAT & GRD \\
\hline 7 years & $\begin{array}{l}-0.015 \\
(0.003)\end{array}$ & $\begin{array}{l}-0.012 \\
(0.003)\end{array}$ & $\begin{array}{l}-0.016 \\
(0.003)\end{array}$ & $\begin{array}{l}-0.010 \\
(0.003)\end{array}$ & $\begin{array}{l}-0.009 \\
(0.007)\end{array}$ & $\begin{array}{l}-0.009 \\
(0.007)\end{array}$ \\
\hline 8 years & $\begin{array}{l}-0.022 \\
(0.003)\end{array}$ & $\begin{array}{l}-0.018 \\
(0.003)\end{array}$ & $\begin{array}{l}-0.021 \\
(0.003)\end{array}$ & $\begin{array}{l}-0.014 \\
(0.003)\end{array}$ & $\begin{array}{l}-0.021 \\
(0.006)\end{array}$ & $\begin{array}{l}-0.015 \\
(0.006)\end{array}$ \\
\hline 9 years & $\begin{array}{l}-0.040 \\
(0.004)\end{array}$ & $\begin{array}{l}-0.031 \\
(0.004)\end{array}$ & $\begin{array}{l}-0.039 \\
(0.004)\end{array}$ & $\begin{array}{c}-0.025 \\
(0.004)\end{array}$ & $\begin{array}{c}-0.033 \\
(0.008)\end{array}$ & $\begin{array}{l}-0.020 \\
(0.008)\end{array}$ \\
\hline
\end{tabular}

Notes: All regressions include fixed effects for parent's birth year, state of birth, and census year. Additional controls include race, gender age, and asian ethnicity. Data are grouped into means by parent's birth year, state of birth, and census year, and weighted by cell population size. Huber-White standard errors are shown from clustering by birth cohort and state of birth. The ommited compulsory school law variable indicates whether the minimum years of schooling required before able to obtain a work permit was 6 or less. Samples include all children aged 7 to 15 with U.S. born parents aged 14 between 1915 and 1969. Standard errors are in parenthesis. See text for more data specifics. 
Table 4

OLS Estimates of Effect of Parent's Education on Children's Education

\begin{tabular}{|c|c|c|}
\hline Dependent Var: & Repeat & $\begin{array}{c}<\text { MEDIAN } \\
\text { GRD }\end{array}$ \\
\hline \multicolumn{3}{|c|}{ Full Sample } \\
\hline Dual Parent: Father's Education & $\begin{array}{l}-0.030 \\
(0.001)\end{array}$ & $\begin{array}{l}-0.029 \\
(0.001)\end{array}$ \\
\hline Dual Parent: Mother's Education & $\begin{array}{c}-0.036 \\
(0.001)\end{array}$ & $\begin{array}{l}-0.036 \\
(0.001)\end{array}$ \\
\hline Single Parent: Household Head & $\begin{array}{l}-0.029 \\
(0.002)\end{array}$ & $\begin{array}{l}-0.026 \\
(0.002)\end{array}$ \\
\hline \multicolumn{3}{|c|}{ Parent's Education < 12 years } \\
\hline Dual Parent: Father's Education & $\begin{array}{l}-0.038 \\
(0.002)\end{array}$ & $\begin{array}{l}-0.037 \\
(0.002)\end{array}$ \\
\hline Dual Parent: Mother's Education & $\begin{array}{l}-0.040 \\
(0.002)\end{array}$ & $\begin{array}{l}-0.041 \\
(0.002)\end{array}$ \\
\hline Single Parent: Household Head & $\begin{array}{l}-0.027 \\
(0.002)\end{array}$ & $\begin{array}{l}-0.024 \\
(0.002)\end{array}$ \\
\hline \multicolumn{3}{|c|}{ Parent's Education > 12 years } \\
\hline Dual Parent: Father's Education & $\begin{array}{l}-0.009 \\
(0.002)\end{array}$ & $\begin{array}{l}-0.011 \\
(0.002)\end{array}$ \\
\hline Dual Parent: Mother's Education & $\begin{array}{l}-0.006 \\
(0.002)\end{array}$ & $\begin{array}{l}-0.009 \\
(0.003)\end{array}$ \\
\hline Single Parent: Household Head & $\begin{array}{l}-0.011 \\
(0.003)\end{array}$ & $\begin{array}{l}-0.008 \\
(0.003)\end{array}$ \\
\hline
\end{tabular}


Table 5

IV Effects of Parental Education on Children's Education and Parent's Earnings

\begin{tabular}{|c|c|c|c|}
\hline \multirow[t]{2}{*}{ Dependent Variable: } & Repeat & $\begin{array}{l}<\text { MEDIAN } \\
\text { GRD }\end{array}$ & $\begin{array}{c}\text { Parent's Log } \\
\text { Annual Earnings }\end{array}$ \\
\hline & \multicolumn{3}{|c|}{ Full Sample } \\
\hline Dual Parent: Father's Education & $\begin{array}{l}-0.076 \\
(0.007)\end{array}$ & $\begin{array}{l}-0.059 \\
(0.007)\end{array}$ & $\begin{array}{c}0.115 \\
(0.015)\end{array}$ \\
\hline Dual Parent: Mother's Education & $\begin{array}{l}-0.075 \\
(0.006)\end{array}$ & $\begin{array}{l}-0.049 \\
(0.006)\end{array}$ & $\begin{array}{c}0.205 \\
(0.038)\end{array}$ \\
\hline Single Parent: Household Head & $\begin{array}{l}-0.048 \\
(0.009)\end{array}$ & $\begin{array}{l}-0.027 \\
(0.009)\end{array}$ & $\begin{array}{c}0.202 \\
(0.039)\end{array}$ \\
\hline \multicolumn{4}{|c|}{ Parent's Education < 12 years } \\
\hline Dual Parent: Father's Education & $\begin{array}{l}-0.082 \\
(0.011)\end{array}$ & $\begin{array}{l}-0.073 \\
(0.011)\end{array}$ & \\
\hline Dual Parent: Mother's Education & $\begin{array}{l}-0.081 \\
(0.012)\end{array}$ & $\begin{array}{l}-0.062 \\
(0.013)\end{array}$ & \\
\hline Single Parent: Household Head & $\begin{array}{l}-0.043 \\
(0.016)\end{array}$ & $\begin{array}{l}-0.021 \\
(0.016)\end{array}$ & \\
\hline
\end{tabular}

Notes: All regressions include fixed effects for parent's birth year, state of birth, and census year. Additional controls include race, gender age, and asian ethnicity. Data are grouped into means by parent's birth year, state of birth, and census year, and weighted by cell population size. Huber-White standard errors are shown from clustering by birth cohort and state of birth. Samples include all children aged 7 to 15 with U.S. born parents aged 14 between 1915 and 1969. Standard errors are in parenthesis. See text for more data specifics. 
Table 6

IV Effects of Parents Education on the Probability of Dropping Out of High School

\begin{tabular}{|c|c|c|c|c|}
\hline & $\begin{array}{c}\text { Mean } \\
\text { Dropouts }\end{array}$ & OLS & IV & $\begin{array}{l}\text { Number of } \\
\text { Cells }\end{array}$ \\
\hline \multicolumn{5}{|c|}{ 15-18 year olds } \\
\hline Dual Parent: Father's Education & 0.07 & $\begin{array}{l}-0.017 \\
(0.001)\end{array}$ & $\begin{array}{l}-0.034 \\
(0.005)\end{array}$ & 5,047 \\
\hline Dual Parent: Mother's Education & 0.07 & $\begin{array}{l}-0.022 \\
(0.001)\end{array}$ & $\begin{array}{l}-0.048 \\
(0.006)\end{array}$ & 5,047 \\
\hline Single Parent: Household Head & 0.134 & $\begin{array}{l}-0.020 \\
(0.001)\end{array}$ & $\begin{array}{l}-0.030 \\
(0.008)\end{array}$ & 5,047 \\
\hline \multicolumn{5}{|c|}{ 15-16 year olds } \\
\hline Dual Parent: Father's Education & 0.045 & $\begin{array}{l}-0.012 \\
(0.001)\end{array}$ & $\begin{array}{l}-0.022 \\
(0.005)\end{array}$ & 4,887 \\
\hline Dual Parent: Mother's Education & 0.045 & $\begin{array}{l}-0.016 \\
(0.001)\end{array}$ & $\begin{array}{l}-0.035 \\
(0.007)\end{array}$ & 4,887 \\
\hline Single Parent: Household Head & 0.082 & $\begin{array}{l}-0.013 \\
(0.002)\end{array}$ & $\begin{array}{l}-0.018 \\
(0.010)\end{array}$ & 3,817 \\
\hline
\end{tabular}

Notes: All regressions include fixed effects for parent's birth year, state of birth, and census year. Additional controls include race, gender age, and asian ethnicity. Data are grouped into means by parent's birth year, state of birth, and census year, and weighted by cell population size. Huber-White standard errors are shown from clustering by birth cohort and state of birth. Samples include all children aged 15 to 18 or 15 to 16 residing with a parent that was aged 14 between 1915 and 1969. Standard errors are in parenthesis. See text for more data specifics. 
Table 7

Sensitivity of IV Estimates to Additional Controls

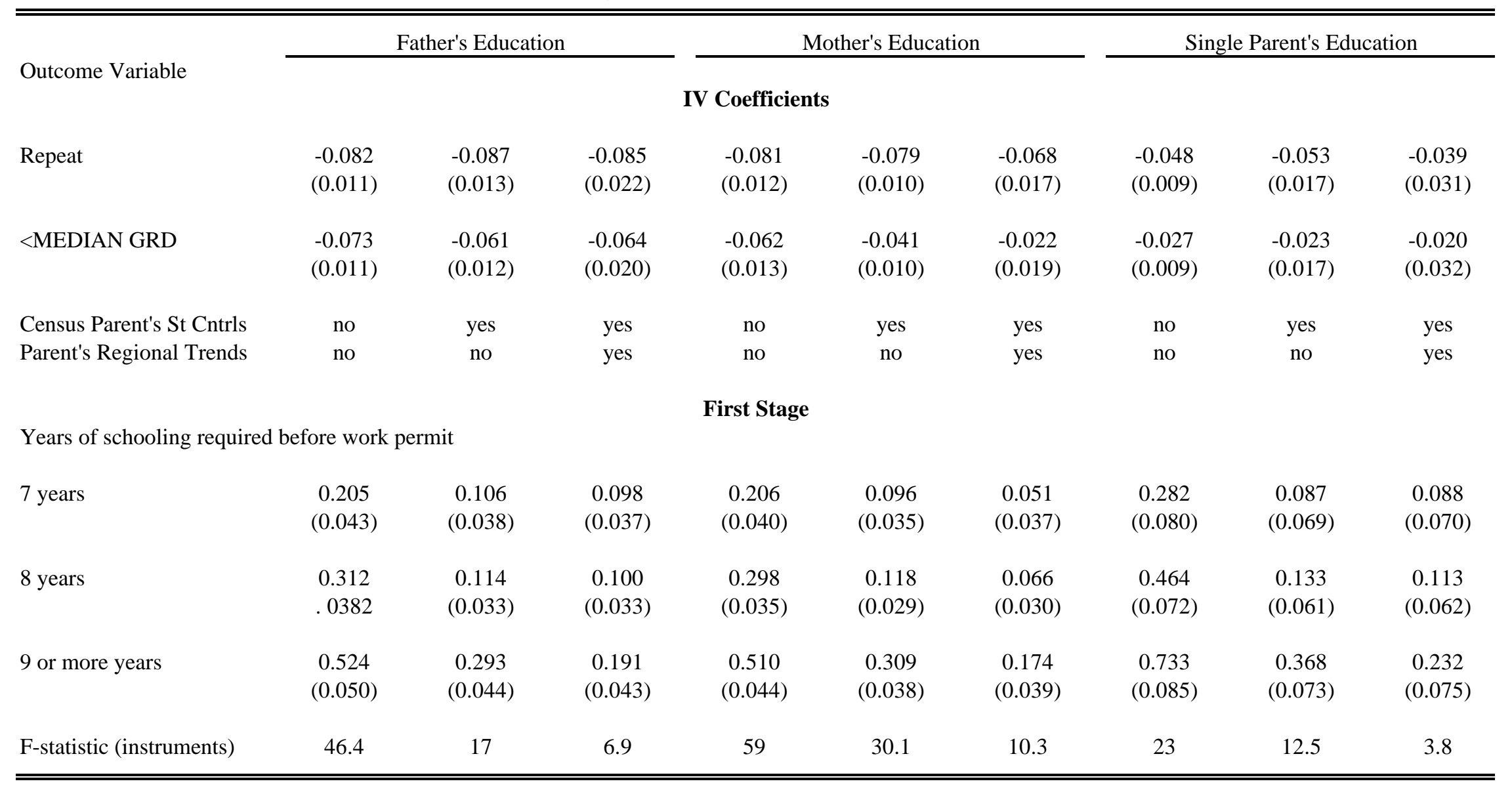

Notes: All regressions include fixed effects for parent's birth year, state of birth, and census year. Additional controls include race, gender age, and asian ethnicity. Census Parent's State Controls include fraction in state black, in the labor force, in the manufacturing sector, residing on a farm, and average age. Data are grouped into means by parent's birth year, state of birth, and census year, and weighted by cell population size. Huber-White standard errors are shown from clustering by birth cohort and state of birth. Samples include all children aged 7 to 15 with U.S. born parents aged 14 between 1915 and 1969 .

Standard errors are in parenthesis. See text for more data specifics. 
Table 8

OLS and IV Estimates for States with a Downward Change in Mandatory School Years

Dependent Variable:

Dual Parent: Father's Education

Dual Parent: Mother's Education

Single Parent: Household Head

Dual Parent: Father's Education

Dual Parent: Mother's Education

Single Parent: Household Head

\begin{tabular}{lcl} 
& $<$ MEDIAN & \\
Repeat & GRD & Cell-size \\
\hline
\end{tabular}

OLS

$\begin{array}{lll}-0.032 & -0.032 & 1009 \\ (0.002) & (0.002) & \\ & & 1009 \\ -0.040 & -0.040 & \\ (0.003) & (0.003) & 929 \\ & & \\ -0.027 & -0.022 & \\ (0.004) & (0.004) & 1009 \\ & & \\ & & \\ -0.060 & -0.069 & \\ (0.017) & (0.019) & \\ & & \\ -0.070 & -0.067 & 929 \\ (0.013) & (0.015) & \\ -0.051 & -0.018 & \\ (0.022) & (0.024) & \end{array}$

Notes: All regressions include fixed effects for parent's birth year, state of birth, and census year. Additional controls include race, gender age, and asian ethnicity. Data are grouped into means by parent's birth year, state of birth, and census year, and weighted by cell population size. HuberWhite standard errors are shown from clustering by birth cohort and state of birth. Standard errors are in parenthesis. See text for more data specifics. 
Table 9

IV Effects of Parent's Education on Child's Education for Different Cohorts of Parents

\begin{tabular}{|c|c|c|c|c|c|c|c|}
\hline & \multicolumn{7}{|c|}{ Year when Parent Aged 14} \\
\hline & Sample & $1915-44$ & $1920-49$ & $1925-54$ & $1930-59$ & $1935-64$ & $1940-69$ \\
\hline Father's & -0.0573 & -0.0362 & -0.0744 & -0.0625 & -0.0555 & -0.0482 & -0.0572 \\
\hline Education & $(0.006)$ & $(0.019)$ & $(0.021)$ & $(0.010)$ & $(0.008)$ & (0.009) & $(0.015)$ \\
\hline Mother's & -0.0491 & -0.0681 & -0.0556 & -0.0516 & -0.049 & -0.0389 & -0.0359 \\
\hline Education & $(0.006)$ & $(0.014)$ & $(0.015)$ & $(0.010)$ & $(0.008)$ & $(0.009)$ & $(0.015)$ \\
\hline Single Parent's & -0.0273 & -0.0475 & -0.0439 & -0.0369 & -0.0354 & -0.0206 & -0.0028 \\
\hline Education & $(0.009)$ & $(0.045)$ & $(0.020)$ & $(0.013)$ & $(0.011)$ & $(0.013)$ & $(0.026)$ \\
\hline \multicolumn{8}{|c|}{$\begin{array}{l}\text { number of states } \\
\text { that changed laws }\end{array}$} \\
\hline (out of 49) & 48 & 44 & 44 & 34 & 36 & 33 & 34 \\
\hline
\end{tabular}

Notes: All regressions include fixed effects for parent's birth year, state of birth, and census year. Additional controls include race, gender age, and asian ethnicity. Data are grouped into means by parent's birth year, state of birth, and census year, and weighted by cell population size. Huber-White standard errors are shown from clustering by birth cohort and state of birth. The full sample includes all children aged 7 to 15 with U.S. born parents aged 14 between 1915 and 1969. Standard errors are in parenthesis. See text for more data specifics. 
Table 10

IV Estimates for Sample of Children in States Different from parent's State of Birth

\begin{tabular}{|c|c|c|c|c|}
\hline \multirow[t]{2}{*}{ Dependent Variable: } & \multicolumn{2}{|c|}{ REPEAT } & \multicolumn{2}{|c|}{ <MEDIAN-GRD } \\
\hline & \multicolumn{2}{|c|}{ OLS } & \multirow[b]{2}{*}{$\begin{array}{l}-0.017 \\
(0.000)\end{array}$} & \multirow[b]{2}{*}{$\begin{array}{l}-0.018 \\
(0.000)\end{array}$} \\
\hline Dual Parent: Father's Education & $\begin{array}{l}-0.016 \\
(0.000)\end{array}$ & $\begin{array}{l}-0.017 \\
(0.000)\end{array}$ & & \\
\hline Dual Parent: Mother's Education & $\begin{array}{c}-0.022 \\
(0.000)\end{array}$ & $\begin{array}{c}-0.022 \\
(0.000)\end{array}$ & $\begin{array}{c}-0.024 \\
(0.000)\end{array}$ & $\begin{array}{c}-0.024 \\
(0.000)\end{array}$ \\
\hline Single Parent: Household Head & $\begin{array}{c}-0.023 \\
(0.001)\end{array}$ & $\begin{array}{c}-0.023 \\
(0.001)\end{array}$ & $\begin{array}{l}-0.022 \\
(0.004)\end{array}$ & $\begin{array}{c}-0.025 \\
(0.001)\end{array}$ \\
\hline \multicolumn{5}{|c|}{ IV } \\
\hline Dual Parent: Father's Education & $\begin{array}{c}-0.071 \\
(0.012)\end{array}$ & $\begin{array}{c}-0.024 \\
(0.003)\end{array}$ & $\begin{array}{c}-0.073 \\
(0.013)\end{array}$ & $\begin{array}{c}-0.026 \\
(0.003)\end{array}$ \\
\hline Dual Parent: Mother's Education & $\begin{array}{c}-0.064 \\
(0.010)\end{array}$ & $\begin{array}{c}-0.022 \\
(0.005)\end{array}$ & $\begin{array}{c}-0.064 \\
(0.011)\end{array}$ & $\begin{array}{c}-0.029 \\
(0.006)\end{array}$ \\
\hline Single Parent: Household Head & $\begin{array}{l}-0.041 \\
(0.017)\end{array}$ & $\begin{array}{c}-0.020 \\
(0.010)\end{array}$ & $\begin{array}{c}-0.041 \\
(0.018)\end{array}$ & $\begin{array}{c}-0.027 \\
(0.010)\end{array}$ \\
\hline Parent's Birthplace Dummies & Yes & No & Yes & No \\
\hline $\begin{array}{l}\text { State of Residence*Parent's } \\
\text { BirthPlace Dummies }\end{array}$ & No & Yes & No & Yes \\
\hline
\end{tabular}

Notes: All regressions include fixed effects for parent's birth year, state of birth, and census year. Additional controls include race, gender age, and asian ethnicity. Data are grouped into means by parent's birth year, state of birth, and census year, and weighted by cell population size. Huber-White standard errors are shown from clustering by birth cohort and state of birth. Standard errors are in parenthesis. See text for more data specifics. 
Table 11

Estimated Simultaneous Effects of Parental Education

\begin{tabular}{|c|c|c|c|}
\hline Dependent Variable: & Repeat & $\begin{array}{l}<\text { MEDIAN } \\
\text { GRD }\end{array}$ & Cell-size \\
\hline \multicolumn{4}{|c|}{ OLS } \\
\hline Dual Parent: Father's Education & $\begin{array}{l}-0.010 \\
(0.000)\end{array}$ & $\begin{array}{c}-0.011 \\
(0.000)\end{array}$ & 1009 \\
\hline Dual Parent: Mother's Education & $\begin{array}{l}-0.018 \\
(0.000)\end{array}$ & $\begin{array}{l}-0.019 \\
(0.000)\end{array}$ & 1009 \\
\hline \multicolumn{4}{|c|}{ IV } \\
\hline Dual Parent: Father's Education & $\begin{array}{l}-0.040 \\
(0.037)\end{array}$ & $\begin{array}{l}-0.089 \\
(0.046)\end{array}$ & 1009 \\
\hline Dual Parent: Mother's Education & $\begin{array}{l}-0.032 \\
(0.042)\end{array}$ & $\begin{array}{c}0.045 \\
(0.053)\end{array}$ & 1009 \\
\hline $\begin{array}{l}\text { F-test: Father and Mother's } \\
\text { Education Effect }=0\end{array}$ & 124.9 & 45.3 & \\
\hline
\end{tabular}

Notes: All regressions include fixed effects for parent's birth year, state of birth, and census year. Additional controls include race, gender age, and asian ethnicity. Data are grouped into means by parent's birth year, state of birth, and census year, and weighted by cell population size. Huber-White standard errors are shown from clustering by birth cohort and state of birth. Standard errors are in parenthesis. See text for more data specifics. 


\begin{tabular}{|c|c|c|c|c|c|c|c|c|}
\hline \multicolumn{9}{|c|}{$\begin{array}{c}\text { Appendix Table } 1 \\
\text { Descriptive Statistics }\end{array}$} \\
\hline & \multicolumn{4}{|c|}{ Dual Parent Families } & \multicolumn{4}{|c|}{ Single Parent Families } \\
\hline & 1960 & 1970 & 1980 & Combined & 1960 & 1970 & 1980 & Combined \\
\hline \multicolumn{9}{|c|}{ Father or Household Head among Single Parent Families } \\
\hline Age & $\begin{array}{l}40.85 \\
(7.26)\end{array}$ & $\begin{array}{l}40.43 \\
(7.13)\end{array}$ & $\begin{array}{l}39.49 \\
(7.09)\end{array}$ & $\begin{array}{l}40.29 \\
(7.18)\end{array}$ & $\begin{array}{l}38.84 \\
(7.93)\end{array}$ & $\begin{array}{l}38.22 \\
(7.68)\end{array}$ & $\begin{array}{l}36.26 \\
(7.20)\end{array}$ & $\begin{array}{l}37.49 \\
(7.61)\end{array}$ \\
\hline Highest Grade & $\begin{array}{l}10.29 \\
(3.64)\end{array}$ & $\begin{array}{l}11.47 \\
(3.39)\end{array}$ & $\begin{array}{l}12.60 \\
(3.27)\end{array}$ & $\begin{array}{l}11.41 \\
(3.56)\end{array}$ & $\begin{array}{c}9.36 \\
(3.35)\end{array}$ & $\begin{array}{l}10.43 \\
(3.06)\end{array}$ & $\begin{array}{l}11.56 \\
(2.66)\end{array}$ & $\begin{array}{l}10.70 \\
(3.08)\end{array}$ \\
\hline \multicolumn{9}{|c|}{ Mother } \\
\hline Age & $\begin{array}{l}37.51 \\
(6.53)\end{array}$ & $\begin{array}{l}37.44 \\
(6.57)\end{array}$ & $\begin{array}{l}36.78 \\
(6.32)\end{array}$ & $\begin{array}{l}37.27 \\
(6.49)\end{array}$ & & & & \\
\hline Highest Grade & $\begin{array}{l}10.56 \\
(2.88)\end{array}$ & $\begin{array}{l}11.38 \\
(2.50)\end{array}$ & $\begin{array}{l}12.17 \\
(2.41)\end{array}$ & $\begin{array}{l}11.35 \\
(2.68)\end{array}$ & & & & \\
\hline \multicolumn{9}{|c|}{ Children } \\
\hline Age & $\begin{array}{l}10.70 \\
(2.52)\end{array}$ & $\begin{array}{l}10.94 \\
(2.55)\end{array}$ & $\begin{array}{l}11.08 \\
(2.57)\end{array}$ & $\begin{array}{l}10.90 \\
(2.55)\end{array}$ & $\begin{array}{l}11.05 \\
(2.56)\end{array}$ & $\begin{array}{l}11.08 \\
(2.57)\end{array}$ & $\begin{array}{l}11.14 \\
(2.58)\end{array}$ & $\begin{array}{l}11.10 \\
(2.57)\end{array}$ \\
\hline Highest Grade & $\begin{array}{l}4.22 \\
(2.57)\end{array}$ & $\begin{array}{l}4.43 \\
(2.62)\end{array}$ & $\begin{array}{c}4.55 \\
(2.64)\end{array}$ & $\begin{array}{l}4.40 \\
(2.61)\end{array}$ & $\begin{array}{c}4.43 \\
(2.63)\end{array}$ & $\begin{array}{c}4.52 \\
(2.65)\end{array}$ & $\begin{array}{l}4.55 \\
(2.62)\end{array}$ & $\begin{array}{l}4.51 \\
(2.63)\end{array}$ \\
\hline Black & 0.09 & 0.10 & 0.10 & 0.10 & 0.32 & 0.34 & 0.37 & 0.35 \\
\hline Female & 0.49 & 0.49 & 0.49 & 0.49 & 0.50 & 0.50 & 0.49 & 0.50 \\
\hline REPEAT & 0.15 & 0.15 & 0.15 & 0.15 & 0.25 & 0.21 & 0.21 & 0.22 \\
\hline$<$ MEDIAN GRD & 0.20 & 0.19 & 0.18 & 0.19 & 0.28 & 0.24 & 0.24 & 0.25 \\
\hline Observations & 233,080 & 266,265 & 211,727 & 711,072 & 26,939 & 45,462 & 57,231 & 129,771 \\
\hline
\end{tabular}

